Scientific Journal Warsaw University of Life Sciences - SGGW

Problems of World Agriculture volume 18 (XXXIII), number 4, 2018: 183-191

DOI: 10.22630/PRS.2018.18.4.109

Slawomir Jarka', Marzena Trajer
${ }^{1}$ Warsaw University of Life Sciences - SGGW, Poland
${ }^{2}$ The National Center of Agricultural Support, Poland

\title{
Support for the Beekeeping Sector in Poland and the European Union
}

\begin{abstract}
The aim of the work was to present a support mechanism for bee products market implemented after Poland's accession to the European Union, including within the framework of national beekeeping support programs. The elaboration included information contained in legal acts of the European Commission, MRiRW and KOWR. Support for the beekeeping sector in Poland and the $\mathrm{EU}$ is related to the policy of sustainable development of agriculture and rural areas. The amount of funds addressed to individual beneficiaries depends on the size of the sector in a given Member State. Spain, France, Greece, Romania and Italy, and Poland received the highest amounts of support under the EU budget.
\end{abstract}

Key words: support, beekeeping sector, sustainable development.

JEL Classification: Q18

\section{Introduction}

Beekeeping, as an economic and social activity, has a significant impact on the natural environment, therefore it is an important element of sustainable development, both in agriculture and rural areas. The aim of the work was to present a support mechanism for bee products market implemented after Poland's accession to the European Union, including within the framework of national beekeeping support programs. Ensuring proper development conditions for the beekeeping sector helps to improve its competitiveness. The presented considerations assume that the support of the beekeeping sector in Poland is justified not only because of economic reasons, but also because of its participation in the creation of public goods. Thus, it affects the level of sustainable development of rural areas. Economic analyses show that due to pollination of entomophilic plants, farmers, fruit-growers and gardeners obtain higher yields, and the products are characterized by higher quality.

\section{Justification of the policy of supporting beekeeping sector in the EU}

Sustainable development assumes the ability of the natural and economic system to selfrenew itself, which is possible due to maintaining the balance of individual ecosystems. Everyone has to respect laws related to the functioning of the natural environment, because there is no human activity that would be indifferent to the environment. This causes the environment

\footnotetext{
${ }^{1} \mathrm{PhD}$, Faculty of Economic Sciences WULS-SGGW, ul. Nowoursynowska 166, 02-787 Warszawa, e-mail: slawomir jarka@sggw.pl; https://orcid.org/0000-0003-0369-9905

2 MSc, Director of the Analysis and Strategy Office, National Center for Agricultural Support in Warsaw, e-mail: marzena.trajer@kowr.gov.pl; https://orcid.org/0000-0003-0269-4758
} 
to be often transformed and destroyed by man. Therefore, the environment should be constantly reproduced, which is of particular importance for agriculture. It is necessary to use the natural environment so that the level of its consumption does not exceed the level of regeneration, and the amount of pollutants flowing into the environment does not exceed its assimilation capacity (Woś, 2004). An important principle of sustainable development is the balance between social, economic and ecological systems. Linking agriculture and the environment directly caused that the concept of "persistent and sustainable development" was also transferred to agriculture, where it resulted in the concept of "persistent and sustainable agriculture" (Juszkiewicz, 2006). It assumes:

- responsibility for management - ethical and aesthetic attitude to nature,

- limiting the production volume by considering the capacity of ecosystems, as well as combining plant and animal production,

- a comprehensive agriculture-oriented work serving not only the production and social benefits of agriculture and rural areas,

- economical use of natural resources,

- limiting the use of means of production that increase productivity,

- prices of agricultural products that take into account economic and ecological aspects,

- preservation of all soil functions as the basis for the functioning of agriculture.

- In the opinion of H. Runowski (2002), sustainable development of agriculture should be equated with sustainable development of rural areas, as agriculture is its basic function and the main owner of the natural environment.

In the concept of sustainable development of rural areas, Siekierski (2003) distinguish four directions:

- protection of rural areas, including protection of the rural landscape, biodiversity and the prevention of erosion,

- protection of soil, water and air against agricultural pollution

- caution in the development of biotechnology and genetic engineering,

- persistent and sustainable development of agriculture.

Sustainable agriculture aims at the use of land resources that does not destroy natural sources and allows to meet the basic needs of next generations of producers and consumers (Urban, 2003; Woś, 2004). According to Smagacz, sustainable agriculture uses the resources of land without destroying its natural sources, which will meet the needs of future generations (Smagacz, 2000). The interest in sustainable agriculture is the result of a critical assessment of intensive farming characterized by a high level of mechanization and specialization (Kuś, 2005). Increasing social incomes as well as increasing quality of life cause that the society's interest in tradition, cultural and landscape values is increasing. Poor undernourished societies struggling with the problems of proper food supply of the population do not have sufficient funds to protect natural resources, on the contrary they are intensively exploited, which unfortunately has a negative impact on the surrounding environment. Therefore, the idea of sustainable development was created as a concept in the face of strong threats in the form of environmental pollution and destabilization of natural systems. Since the dangerous side effects of industrial agriculture have emerged, the creative role of land is rediscovered. Its usefulness is a public good whose protection is the essence of the paradigm of sustainable agriculture (Czyżewski, Brelik, 2013). Analysing the categories of public goods provided by agriculture directly or in the form of external management effects, we can talk about environmental, economic and sociocultural goods (Cooper et al., 2009). 
Beekeeping, as an economic and social activity, plays an important role in the development of rural areas, far beyond the production function. The beekeeping sector is important for agriculture, food security and biodiversity as bees pollinate crops and wild plants.

The importance of bees for agricultural and fruit production is due to the fact that over 70 of the 100 most important crops for humans are pollinated by bees, which provides $30 \%$ of the world's harvest of arable crops (Imhoof, Lieckfeld, 2014). At the same time, the role of honey bees as plant pollinators is becoming more and more important because in the era of widespread chemicalization of agriculture and high environmental pollution, wild bee insects - plant pollinators - have been dying out. Honeybees, as pollinators of entomophilic plants, bring much greater benefits to the human economy than the production of honey, pollen, wax, propolis and royal jelly.

It is estimated that $1 / 3$ of products consumed by man is dependent directly or indirectly on pollination by insects (Koltowski, 2016). The various functions of beekeeping are at risk due to the decline in bee populations caused by, among others, the use of pesticides, bee diseases, changing climatic and environmental conditions, and the loss of biodiversity.

The economic value of pollination by bees goes beyond agricultural production, as bees also pollinate non-agricultural species of plants. Bee pollination provides a balance between indigenous species and newly introduced to the ecosystem, controls soil erosion, which indirectly affects the human life environment.

The presented arguments justify providing financial support for the beekeeping sector, which will allow to keep as many bee colonies as possible in order to meet the needs of agriculture, the natural non-agricultural environment and supply the market with a sufficient amount of high quality honey and other bee products.

The presented considerations assume that the support of the beekeeping sector in Poland is justified not only because of economic reasons (contributes to the economic growth of the entire agriculture), but also because of its participation in the creation of public goods. Thus, it affects the level of sustainable development of rural areas. Economic analyzes show that due to pollination of entomophilic plants, farmers, fruit-growers and gardeners obtain higher yields, and the produced products are characterized by higher quality. As indicated by Majewski (2012), the limited possibility of replacing bees in pollination of plants results in the inability to abandon the rearing of these insects without adversely affecting crops and the natural environment. This is the basis for state intervention in support of beekeeping. Support for the apiculture industry has been used in the EU since 1997 as an important element of the common agricultural policy. In all EU countries, programs supporting the beekeeping sector are implemented.

\section{Data and research methods}

To implement the adopted research objective consisting in defining the support mechanism for the bee products market in Poland and the European Union, the elaboration included information contained in legal acts of the European Commission and information from the Ministry of Agriculture and Rural Development. Secondary data from reports on the activity of the Agricultural Market Agency in the years 2004-2018 and the report on the activity of the National Center for Agricultural Support in 2017 and literature on the subject were also used. Issues regarding support for apiculture in the proposed Common Agricultural Policy in the next EU budget perspective for 2021-2027 were also presented. The results of the analysis are presented in a descriptive, tabular and graphic form. 


\section{Support for bee products market in Poland and the EU}

Support for the beekeeping industry has been used in the European Union since 1997 as an important element of the common agricultural policy. Co-financing of the Member States' activities by the European Commission on the bee products market is dictated by the need to: develop rural areas, unify production conditions and sell bee products, maintain ecological balance, prevent the fragmentation of honey production and trade, combat bee disease (varroosis) and balance the demand for honey with its supply.

Table 1. The amount of the Union contribution to national apiculture programs in 2017-2019 [EURO]

\begin{tabular}{|c|c|c|c|}
\hline Details & Beekeeping year 2017 & $\begin{array}{c}\text { Beekeeping year } \\
2018\end{array}$ & $\begin{array}{c}\text { Beekeeping year } \\
2019\end{array}$ \\
\hline Belgium & 249313 & 249313 & 249313 \\
\hline Bulgaria & 1216533 & 1216534 & 1216533 \\
\hline Czech Republic & 1250510 & 1250511 & 1250509 \\
\hline Denmark & 174202 & 174202 & 174202 \\
\hline Germany & 1645049 & 1645050 & 1645048 \\
\hline Estonia & 82800 & 82800 & 82800 \\
\hline Ireland & 36333 & 36333 & 36333 \\
\hline Greece & 3632500 & 3632500 & 3632500 \\
\hline Spain & 5634999 & 5635001 & 5634999 \\
\hline France & 3783641 & 3783645 & 3783640 \\
\hline Croatia & 1127767 & 1127767 & 1127767 \\
\hline Italy & 3045356 & 3045357 & 3045354 \\
\hline Cyprus & 100000 & 100000 & 100000 \\
\hline Latvia & 193810 & 193810 & 193810 \\
\hline Lithuania & 324090 & 324090 & 324090 \\
\hline Luxembourg & 18049 & 18049 & 18049 \\
\hline Hungary & 2517625 & 2517627 & 2517624 \\
\hline Malta & 8333 & 8333 & 8333 \\
\hline Netherlands & 173986 & 173971 & 174000 \\
\hline Austria & 870712 & 870712 & 870711 \\
\hline Poland & 2961910 & 2961911 & 2961908 \\
\hline Portugal & 1299259 & 1299259 & 1299259 \\
\hline Rumaunia & 3584747 & 3584749 & 3584744 \\
\hline Slovenia & 382814 & 382814 & 382814 \\
\hline Slovakia & 589423 & 589423 & 589422 \\
\hline Finland & 115637 & 115637 & 115637 \\
\hline Sweden & 346911 & 346911 & 346911 \\
\hline United Kingdom & 633691 & 633691 & 633690 \\
\hline UE-28 & 36000000 & 36000000 & 36000000 \\
\hline
\end{tabular}

Source: Authors' own description. based on the decision of the European Commission. 


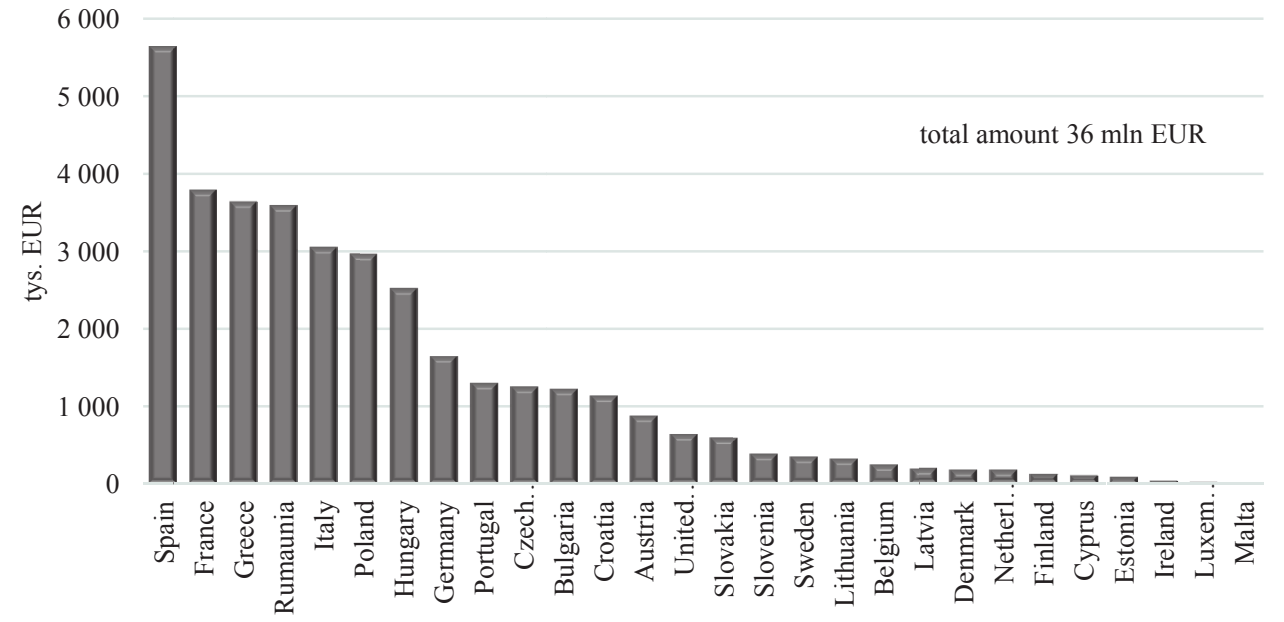

Fig. 1. Amount of the Union contribution to national apiculture programs in the beekeeping year 2019

Source: Authors' own description. based on the decision of the European Commission.

The possibility of providing assistance in the EU beekeeping sector is provided for in art. 55 of Regulation (EU) No 1308/2013 of the European Parliament and of the Council. Member States' activities in this area are carried out based on three-year national support programs for apiculture approved by the European Commission. On the basis of the Commission Decision of 5 July 2016 approving programs to improve the production and marketing of bee products submitted by Member States under Regulation (EU) No 1308/2013 of the European Parliament and of the Council, the amounts of the Union contribution to national apiculture programs were approved for beekeeping years 2017, 2018 and 2019. This Decision approves the national programs for the production and marketing of bee products beekeeping for the years 2017, 2018 and 2019. The amounts of the Union contribution to the national apiculture programs for the apiculture years 2017, 2018 and 2019 for Member States that have approved national programs are presented in the following table 1. From the data presented in Chart 1, it is seen that Spain, France, Greece, Romania and Italy received the highest amounts of support under the Union budget. Poland ranks sixth in terms of the allocated budget.

\section{National programs for Supporting Beekeeping in Poland for 2016-2019}

In accordance with EU rules, co-financing from the EU budget may account for up to $50 \%$ of the funds spent. Total or partial (depending on the direction of support) net costs incurred for the implementation of actions specified in the EC implementing decision by authorized entities, i.e. beekeeping associations, beekeeping clubs, beekeeping incorporations, apiculture cooperatives, groups of agricultural producers (in the beekeeping activities), and producer organizations are subject to a refund. The final recipients of the support are beekeeping farms with a veterinary identification number or apiaries entered into registers kept by district veterinary surgeons. 
Refunds are subject to costs incurred for: purchase of beekeeping equipment and training, purchase of medicines to combat varroosis (admitted to trading in Poland), purchase of equipment for conducting a wandering economy, analysis of honey quality, as well as purchase of mothers, packages and bee sacks.

In 2018, the CAP mechanism "Support for bee products market" was implemented in Poland under the "National Program for Supporting Beekeeping in Poland for 2016/17; 2017/18; 2018/19 "approved by the European Commission by the decision of July 5, 2016 (KOWR, 2018). According to art. 6 par. 2 point 7 of the Act of 9 May 2008 on the Agency for Restructuring and Modernization of Agriculture (Journal of Laws of 2017, item 2137, as amended), from 1 September 2017, the mechanism of the CAP "Support for the bee products market" is delegated to KOWR from the EU paying agency (ARiMR).

Table 2. Funds disbursed under the support programs for beekeeping in 2005-2017 according to the directions of support (PLN thousand)

\begin{tabular}{|c|c|c|c|c|c|c|c|}
\hline Lata & $\begin{array}{l}\text { Technical } \\
\text { support }\end{array}$ & $\begin{array}{l}\text { Purchase of } \\
\text { medicines }\end{array}$ & $\begin{array}{l}\text { Purchase of } \\
\text { devices for the } \\
\text { management of } \\
\text { bee migration }\end{array}$ & $\begin{array}{l}\text { Purchase } \\
\text { of bees }\end{array}$ & $\begin{array}{l}\text { Analysis of } \\
\text { honey } \\
\text { quality }\end{array}$ & $\begin{array}{l}\text { Research } \\
\text { projects }\end{array}$ & Total \\
\hline 2005 & 1077 & 4530 & 862 & 2227 & 190 & 502 & 9388 \\
\hline 2006 & 2074 & 4662 & 1598 & 4717 & 397 & 150 & 13598 \\
\hline 2007 & 1825 & 6476 & 1301 & 5577 & 568 & 13 & 15760 \\
\hline 2008 & 867 & 6483 & 9 & 7177 & 297 & 47 & 14880 \\
\hline 2009 & 789 & 6718 & 6 & 8843 & 214 & & 16570 \\
\hline 2010 & 1096 & 7280 & 11 & 7578 & 427 & & 16392 \\
\hline 2011 & 6334 & 6750 & 703 & 4362 & 121 & & 18270 \\
\hline 2012 & 6667 & 7949 & 567 & 5220 & 119 & & 20522 \\
\hline 2013 & 6634 & 7628 & 481 & 4150 & 117 & & 19010 \\
\hline 2014 & 8491 & 7137 & 584 & 3721 & 167 & & 20100 \\
\hline 2015 & 8690 & 7304 & 471 & 3861 & 136 & & 20462 \\
\hline 2016 & 9656 & 7512 & 590 & 3843 & 133 & & 21734 \\
\hline 2017 & 12314 & 8106 & 763 & 3618 & 70 & & 24871 \\
\hline Total & 66514 & 88535 & 7946 & 64894 & 2956 & 712 & 231557 \\
\hline
\end{tabular}

Source: own study based on reports from the Agricultural Market Agency in the years 2005-2016 and from 2017 on the activity report of the National Center for Agricultural Support.

The analysis in 2005-2017 shows that under the national beekeeping support programs aimed at improving the conditions of production and marketing of bee products, the largest cofinancing after Poland's accession to the European Union covered: purchase of medicines against varroosis (88.5 million PLN) and technical assistance for beekeepers (PLN 66.5 million), colonization of beehives (PLN 64.9 million).

After Poland's accession to the EU by the end of 2017, as part of the implementation of support for bee products market, 3.7 thousand contracts were settled, in which PLN 231.6 million (net) was spent, including PLN 115.8 million (50\%) from the EU budget and the remaining $50 \%$ from the national budget (Figure 2). 


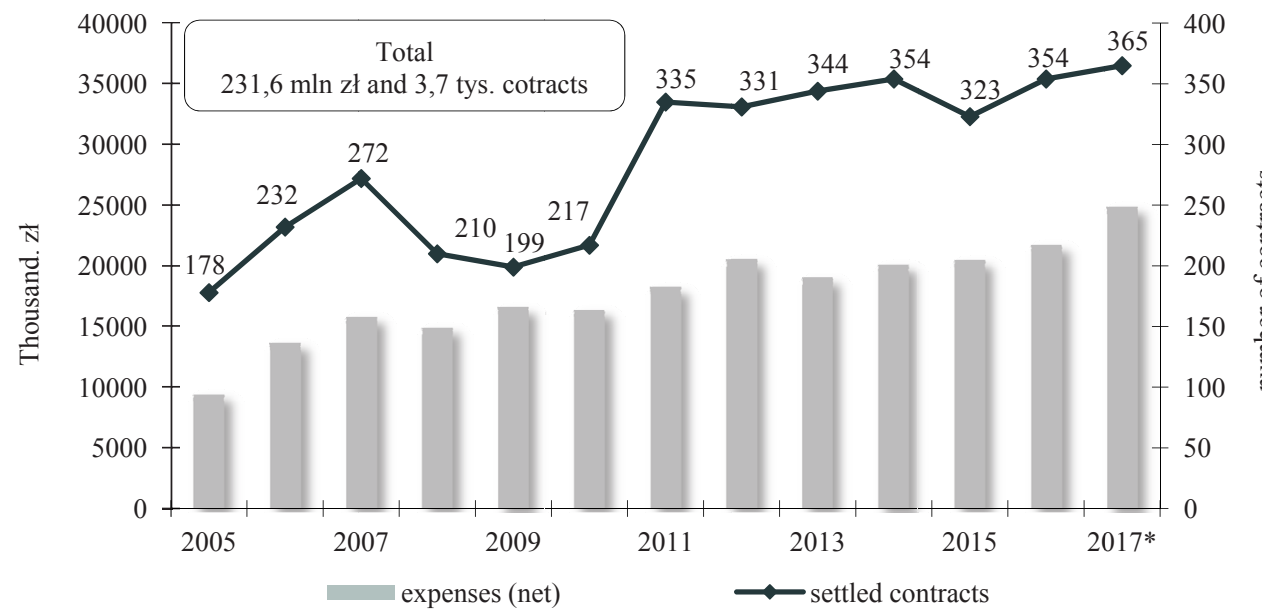

Fig. 2. Implementation of the market support for bee products in 2005-2017

Source: Report on the activities of the National Center for Agricultural Support

\section{Support for bee products market in the $2017 / 2018$ beekeeping season}

For activities in the beekeeping sector in the 2017/2018 season, Poland received EUR 5,924 from the EU (PLN 24,744 (EU Commisiion 2014). In October 2017, the National Centre for Agricultural Support published a call for submission of projects under the mechanism "Support for bee products market" in the 2017/2018 season. The deadline for submission of projects expired on November 30, 2017. The data regarding the implementation of the mechanism is presented in the table below.

Table 3. Types of projects under the mechanism "Support for bee products market" in the 2017/2018 season (as of $30 / 06 / 2018)$

\begin{tabular}{cl|ccc}
\hline Lp. & The name of the activity & Complex projects & Signed contracts & $\begin{array}{c}\text { Value of projects } \\
\text { in thous. zł }\end{array}$ \\
\hline 1. & Training and conferences & 52 & 51 & 756 \\
2. & Purchase of medicines & 88 & 88 & 6516 \\
3. & $\begin{array}{l}\text { Purchase of devices for } \\
\text { the management of bee }\end{array}$ & 64 & 64 & 1381 \\
& $\begin{array}{l}\text { migration } \\
\text { 4. }\end{array}$ & 33 & 33 & 137 \\
Performing honey quality & analyzes & 83 & 83 & 3723 \\
6. & $\begin{array}{l}\text { Purchase of bees } \\
\text { Purchase of beekeeping }\end{array}$ & 87 & 86 & 12227 \\
& equipment & 407 & 405 & 24740 \\
\hline
\end{tabular}

Source: Report on the activities of the National Center for Agricultural Support. 
In total, 407 projects were submitted to KOWR for a total of PLN 44627 . The largest number of projects concerned the purchase of medicines to combat varroosis - $22 \%$ of all submitted projects, then purchase of beekeeping equipment - $21 \%$ and purchase of bees $-20 \%$. After considering the projects and the necessary division of available funds by the project selection committee, 405 projects for PLN 24,740 thousand were accepted for implementation.

Due to the significant problem for the production of honey, which is the spread of varroosis and bearing in mind the health of bees, it will be necessary to continue activities supporting this sector at the level of the European Union in the next budget perspective.

\section{Conclusion}

1. It can be stated due to the analysis of the literature on the subject of research, support for the beekeeping sector in Poland and the EU is related to the policy of sustainable development of agriculture and rural areas.

2. Beekeeping, as an economic and social activity, plays an important role in the development of rural areas, going far beyond the production function.

3. Support for the beekeeping sector in the EU is systemic and is part of the CAP.

4. The amount of funds addressed to individual beneficiaries depends on the size of the sector in a given Member State.

5. Spain, France, Greece, Romania and Italy, and Poland received the highest amounts of support under the EU budget.

6. Public goods and intrinsic land productivity - deliberations in the context of the paradigm of sustainable agriculture.

\section{References}

Cooper, T. Kaley, H. Baldock, D. (2009). Conceptual Framework on Public Goods Provided Through Agriculture in the EU. Working Document of the Technical Working Group Public Goods, European Network for Rural Development, 2-4.

Czyżewski, B. Brelik, A. (2013). Public goods and intrinsic land productivity - deliberations in the context of the paradigm of sustainable agriculture. Oeconomia Acta Scientiarum Polonorum, 12(14), 31-40.

EU Commission Regulation (2014). No. 907/2014 of 11 March 2014, art. 34.

Imhoof, M. Lieckfeld, C. P. (2014). More than honey. The survival of bees and the future of our world. Wyd. David Suzuki Foundation i Greystone Books, Vancouver/Berkeley. 127-135.

Juszkiewicz, W. (2006). Znaczenie rolnictwa ekologicznego w kontekście idei zrównoważonego rozwoju. W: Zrównoważony rozwój w teorii i praktyce (The importance of organic agriculture in the context of sustainable development. In: Sustainable development in theory and practice). Wyd. Naukowe we Wrockawiu.

Kołtowski, Z. (2006). Znaczenie pszczoły miodnej w zapylaniu roślin entomofilnych (The importance of the honeybee in pollinating entomophilic plants). Downloaded 6.12.2018 from: https://www.pasieka24.pl/wszystkie-nr-pasieki/49pasieka-22007-/665-znaczenie-pszczoy-miodnej-w-zapylaniu-rolin-entomofilnych.html

Krajowy Program Wsparcia Pszczelarstwa w Polsce na lata 2016/17; 2017/18; 2018/19, MRiRW (The National Center of Agricultural Support for 2016/17; 2017/18; 2018/19). Downloaded 6.12.2018 from: https://www.gov.pl/ documents/912055/913531/KPWP+2016-2019.PDF/a28f29ff-231b-b6ba-cee9-c171c9dc58b9

Kuś, J. (2005). Ekologiczne podstawy integrowanej produkcji roślinnej. Materiały szkoleniowe IUNG (Ecological basis of integrated plant production. Training materials). LODR Końskowola, Puławy, 101-108.

Majewski, J. (2012). Wsparcie pszczelarstwa po wejściu Polski do Unii Europejskiej (The beekeeping support after Poland's accession to the EU). Roczniki Naukowe SERIA, 14(2), 113-117.

Rozporządzenie Parlamentu Europejskiego i Rady UE nr 1308/2013 z dnia 17 grudnia 2013 r. ustanawiające wspólną organizację rynków produktów rolnych oraz uchylające rozporządzenia Rady (Regulation No 1308/2013 of the 
European Parliament and of the Council of the European Union of 17 December 2013 establishing a common organization of the markets in agricultural products and repealing Council Regulations). nr 922/72, (EWG) nr 234/79, (WE) nr 1037/2001 i (WE) nr 1234/2007, z późn. zm.

Runowski, H. (2002). Rozwój zrównoważony rolnictwa i gospodarstw rodzinnych (Sustainable development of agriculture and family farms). Wieś i Rolnictwo, IERiGŻ, IRWiR PAN, Warszawa.

Siekierski, J. (2003). Zrównoważony rozwój rolnictwa i wsi w świetle Narodowego Planu Rozwoju i Traktatu Akcesyjnego do Unii Europejskiej (Sustainable development of agriculture and villages in the light of the National Development Plan and Accession Treaty to the European Union). Acta Agraria et Silvestria Series Agronomia Sekcja Ekonomiczna, XL, 5-13.

Smagacz, J. (2000). Rola zmianowania w rolnictwie zrównoważonym (The role of shifting in sustainable agriculture). Pamiętnik Pulawski, 120, 411-414.

Urban, S. (2003). Rola ziemi w rolnictwie zrównoważonym a aktualne jej zasoby w Polsce (The role of land in sustainable agriculture and its current resources in Poland). Acta Agraria et Silversia Series Agraria. Sekcja Ekonomia, XL, 25-36.

Woś, A. (2004). W poszukiwaniu modelu rozwoju polskiego rolnictwa (In search of a model for the development of Polish agriculture). IERiGŻ, Warszawa.

\section{For citation:}

Jarka S., Trajer M. (2018). Support for the Beekeeping Sector in Poland and the European Union. Problems of World Agriculture, 18(4), 183-191; DOI: 10.22630/PRS.2018.18.4.109 